DOI: 10.2478/tperj-2013-0010

\title{
The influence of lifestyle on cardio-metabolic risk in students from Timisoara University Center
}

\section{Mihaela ORAVIȚAN', Claudiu AVRAM², Stela IURCIUC ${ }^{3}$, Petru MERGHEȘ ${ }^{4}$, Bogdan ALMĂJAN-GUȚ $\breve{~}^{5}$}

\begin{abstract}
This study is a part of the activities in a cross border cooperation project that has proposed the management of obesity and cardiometabolic risk at students from Timisoara and Szeged university centres. The target group of Timisoara University Center was formed out of 600 students enrolled in the four major universities from Timisoara; target group students were questioned about their lifestyle and were evaluated anthropometric parameters, body composition and arterial stiffness; based on questionnaires was determine too the risk of developing cardiovascular disease and/or diabetes mellitus type II. Analysis of the results revealed the strong correlations between lifestyle and cardio-metabolic risk in these students.
\end{abstract}

Key words: obesity, cardio-metabolic risk, lifestyle, students, Timișoara

Acknowledgement: This study was financed by Hungary-Romania Crossborder Programme, in the project entitled Obesity and cardiometabolic risk management in students from Timișoara and Szeged University Centres, code HURO 116/1001/2.4.2, acronyme RISKRED, www.riskred.eu.

\section{Rezumat}

Acest studiu face parte din activitățile derulate în cadrul unui proiect de cooperare transfrontalieră care și-a propus managementul obezității și al riscului cardio-metabolic la studenții din centrele universitare Timișoara și Szeged. Grupul-țintă din centrul universitar Timișoara a fost format din 600 de studenți înmatriculați în cele 4 universități mari din Timișoara; studenții din grupulțintă au fost chestionați cu privire la stilul de viață și s-au evaluat parametrii antropometrici, compoziția corporală și rigiditatea arterială; pe baza chestionarelor s-a determinat și riscul de a dezvolta boli cardio-vasculare și/sau diabet zaharat de tip II. Analiza rezultatelor a permis evidențierea unor corelații puternice între stilul de viață și riscul cardio-metabolic la acești studenți.

Cuvinte cheie: obezitate, risc cardio-metabolic, stil de viață, studenți, Timișoara.

Precizare: Acest studiu a fost finanțat prin Programul de Cooperare Transfrontalieră Ungaria-România în cadrul proiectului cu titlul Obesity and cardio-metabolic risk management in students from Timișoara and Szeged University Centres, cod HURO 116/1001/2.4.2, acronim RISKRED, www.riskred.eu.

\footnotetext{
${ }_{2}^{1}$ Assoc. Prof. PhD, West University of Timișoara, Faculty of Physical Education and Sports, e-mail: mihaela.oravitan@gmail.com

${ }^{2}$ Assoc. Prof. PhD, West University of Timișoara, Faculty of Physical Education and Sports

${ }^{3}$ Assist. Lecturer PhD, "Victor Babeș" Medicine and Pharmacy University of Timișoara, Faculty of Medicine

${ }^{4}$ Lecturer PhD, University of Agricultural Sciences and Veterinary Medicine of Banat Timișoara, Department of Physical Education and Sports

${ }^{5}$ Lecturer PhD, "Politechnik" University of Timișoara, Department of Physical Education and Sports
} 


\section{Introduction}

"Obesity and cardio-metabolic risk management in students from Timișoara and Szeged University Centres" (acronym RISKRED, project code $1001 / 116 / 2.4 .2$.) was the title of a project coordinated and implemented in a partnership between the West University of Timișoara (as lead partner) and the University of Szeged, Hungary (as project partner); this project was financed by the European Union - European Regional Development Fund, Hungary-Romania Cross-Border Co-operation Programme 2007-2013 [1-3].

Our premise in this project was that a true health problem in this cross-border area is a high prevalence of obesity, mainly due to the bad nutritional habits of the citizens from this geographical area and, secondary, to a modern lifestyle characterized by a low level of physical activity and high level of stress. Also, it is known the higher prevalence of cardiovascular and metabolic diseases related to obesity in this part of Romania and in the cross-border Hungarian area (EuroAspire surveys)[4]. The main etiological factors incriminated were: sedentary lifestyle and unhealthy diet. The epidemiological data, the cross-border traditional diet (high in saturated fat and sugar intake, poor fish, fresh vegetables and fruits consumption) and a preliminary analysis of the target group needs, conduct us for initiating this project proposal. We proposed a complex management program for 1000 students, which involves evaluation of cardio-metabolic risk and specific lifestyle interventions (dietary habits, physical activity, smoking, and stress management) according to current European Guidelines. Our objectives were related to these common threats and are not limited by boundaries. The target group of Romanian partner was formed by 600 students from Timișoara university centre. We suppose that the incidence of cardio-metabolic diseases - a common threat in this area - will decrease due to this kind of action.

The obesity management is a complex and difficult issue; such a cross-border prospective for a common health problem, could be innovative from the point of view of its trans-disciplinary approach; our team consisted of doctors and physical education teachers - so the main aspects (dietary counselling and physical training) of obesity treatment are covered. Other innovative aspects of our project are the assessment of cardio-metabolic risk on a young and overweight population, followed by reinforcement in lifestyle changes, and the use of activemeters (pedometers and pulsemeters) for monitoring the daily physical activity and exercise training intensity. This structured intervention is cost-effective and will have a positive impact on the onset of obesity related cardio-metabolic diseases (diabetes mellitus, ischemic heart disease, stroke etc.). Until now, there is no other cross-border cooperation on this theme, despite the fact that obesity is a well-known health problem in both countries.

The added value of the project consisted in the preventive educational measures and reflected a common needs of the border area which requires common solutions. This was contributing to an increased awareness of cardio-metabolic risk in the young population, which will have a long lasting effect on prevention of cardiovascular and metabolic disease, an increased social integration and quality of life of overweight students by involving them in lifestyle changing activities, increased degree of socialization in the cross-border area in the field of healthcare prevention; also, it was considered that educational interventions of the two partners for the purpose of improving the obesity management were harmonized and a 
preventive culture among young population which in future will have a good impact on the health of the population was developed.

Our proposal was integrated in the general program by widening the area of collaboration with institutions in the EU, in view of harmonizing the interventions for reducing the cardio-metabolic risk and obesity, a common threat in the European healthcare system. At the national level, The Romanian Heart Foundation (part of the European Heart Network), is stated in 2010 its mission: "to prevent the cardiovascular diseases and to reduce mortality by $10 \%$ caused by the cardiovascular diseases until 2015" [5]. Healthcare is having an exceptional importance in the social and economic development of the DKMT region.

\section{Participants and methods}

The target group of the project was composed by 1000 overweight and obese students (600 from the Timisoara University Center - from the West University of Timișoara, the "Victor Babes" Medicine and Pharmacy University of Timisoara, the Banat University of Agricultural Sciences and Veterinary Medicine Timisoara and the Politechnic University, and 400 students from the University of Szeged), from a total number of 50000 students. The evaluation protocol consisted in: assessment of body composition and cardio-metabolic risk (weight, waist circumference, fat, active mass, visceral fat area, waist to hip ratio, blood pressure, arterial stiffness and autonomic function, total cardiovascular risk and risk of diabetes). It were used the research devices already present in our institutions (In-Body 720 Body Composition Analyser, pedometers, pulsemeters) completed with a device for arterial stiffness measurement acquired in the project. There were also questionnaires: 1. about dietary habits, unhealthy habits (smoking), physical activity level 2. SCORE charts - for evaluation of total cardiovascular risk and 3. FINDRISK for the risk of diabetes [2, 3].

Arterial stiffness is an independent predictor of cardiovascular and total mortality. The device used in this study was Sphygmocor, a non-invasive assessment of the cardiovascular system, focused on central blood pressures, measures of arterial stiffness and autonomic function. SphygmoCor technology is the gold standard for non-invasive measurement of central blood pressure and pulse wave velocity. Featured in hundreds of published studies, it is used in leading medical centres and in pharmaceutical clinical trials worldwide. SphygmoCor systems record the patient's radial pulse waveform through a measurement taken at the wrist, derive the blood pressure waveform at the ascending aorta and report vital central blood pressure data. The SphygmoCor system also measures pulse wave velocity (PWV) between two arterial locations. The technology that powers these products is cantered on an algorithm that derives the pressure wave at the ascending aorta from an external measurement taken at the radial artery.

There are studies that clearly demonstrated that pulse wave velocity and augmentation index are associated with the structural changes of atherosclerosis [6].

The augmentation index (Aix) is a ratio calculated from the blood pressure waveform, it is a measure of wave reflection and arterial stiffness. Augmentation index is commonly accepted as a measure of the enhancement (augmentation) of central aortic pressure by a reflected pulse wave. Augmentation index is a sensitive marker of arterial status: it has been shown to be a predictor of adverse cardiovascular events in a variety of patient populations, and higher augmentation index is associated with target organ damage [48]. Recent 
Timişoara Physical Education and Rehabilitation Journal

studies showed that in subjects with and without cardiovascular disease, augmentation index was correlated with diastolic blood pressure, heart rate, height and gender. Age was found to be significantly correlated with augmentation index only in healthy subjects but not in those with atherosclerotic disease [8].

Pulse Wave Velocity (PWV) The arterial PWV, especially of the aorta (PWVAo), has emerged as an important independent predictor of cardiovascular events. PWV increases with stiffness and is defined by the Moens-Korteweg equation, $P W V=\sqrt{ }(E h / 2 \rho R)$, where $E$ is Young's modulus of the arterial wall, $h$ is wall thickness, $\mathrm{R}$ is arterial radius at the end of diastole, and $\rho$ is blood density. There are a number of different ways to measure PWV, and these are generally simple to perform. The arterial pulse wave is recorded at a proximal artery, such as the common carotid, as well as at a more distal artery, such as the femoral. The superficial location of the carotid and femoral arteries means that their pulse waveforms are readily measured noninva-sively, and between these 2 sites the pulse wave has to travel through most of the aorta, an artery particularly prone to the development of athero-sclerosis. The time delay between the arrival of a predefined part of the pulse wave, such as the foot, at these 2 points, is obtained either by simultaneous measurement, or by gating to the peak of the R-wave of the ECG. The distance travelled by the pulse wave is measured over the body surface and PWV is then calculated as distance/time $(\mathrm{m} / \mathrm{s})$. The measured distance is an estimate of the true distance travelled and depends to some extent on body habitus. Furthermore, the abdominal aorta tends to become more tortuous with the age of 34 , potentially leading to an underestimation of PWV $[9,10]$. In the case of hypertensive people without a history of overt cardiovascular disease PWV also predicts the occurrence of cardiovascular events independently of classic risk factors [134]. Once again, PP was of predictive value in univariate but not multivariate analysis. Aortic PWV $>13 \mathrm{~m} / \mathrm{s}$ is a particularly strong predictor of cardiovascular mortality in hypertension [11]. Recently published data showed that carotidfemoral PWV increases at a faster rate in treated hypertensives than in normotensive controls, although where BP was well controlled PWV progression was attenuated [12, 13].

These kind of measurements allowed us to establish the prevalence of cardio-metabolic risk factors among students in the cross-border area - this study was the first survey in our region which had such a complex approach with a large number of young subjects. In the same time, the evaluation increased the awareness and motivated the students from target group to participate in the educational activities of the project.he two university centres.

\section{Results}

The evaluation process gave us instant results which were discussed with each subject in the programme in the same session. It was developed a preventive strategy by implementing this project which is applicable in young overweight patients and consists in 3 major mechanisms: evaluation, recommendations and follow-up [2, 3].

The results regarding lifestyle (physical activity level) are presented in figures 1-4; the eating behaviours are presented in a previouse article [9]. The results regarding the cardiometabolic risk are presented in figures 5-11 and in tables I-III; The statistical analysis was made with GraphPad Prism Software. 
Table 1. Average hemodynamic parameters of students from Timisoara University centre

Aix: augumentation index; PWV: pulse wave velocity; SBPao: Aortic systolic blood pressure; Sys: Brahial systolic blood pressure; Dia: Brahial diastolic blood pressure; MAP: Brahial mean arterial blood pressure; PP: pulse pressure; HR: Heart rate.

\begin{tabular}{lllllllll}
\hline & $\begin{array}{l}\text { Aix aortic: } \\
{[\%]}\end{array}$ & $\begin{array}{l}\text { PWVao } \\
{[\mathrm{m} / \mathrm{s}]}\end{array}$ & $\begin{array}{l}\text { SBPao } \\
{[\mathrm{mmHg}]}\end{array}$ & $\begin{array}{l}\text { Sys } \\
{[\mathrm{mmHg}]}\end{array}$ & $\begin{array}{l}\text { Dia } \\
{[\mathrm{mmHg}]}\end{array}$ & $\begin{array}{l}\text { MAP } \\
{[\mathrm{mmHg}]}\end{array}$ & PP [mmHg] & HR [1/min] \\
\hline Minimum & 3 & 3.8 & 79 & 92 & 46 & 63 & 30 & 38 \\
Maximum & 62.5 & 11.9 & 155 & 159 & 98 & 115 & 85 & 120 \\
Mean & 13.1 & 6.63 & 109 & 121 & 70 & 87 & 51 & 70.9 \\
Std. Deviation & 9.2 & 1.35 & 11.6 & 12.1 & 9.14 & 9.26 & 9.09 & 11.4 \\
Std. Error & 0.404 & 0.0574 & 0.495 & 0.497 & 0.374 & 0.379 & 0.372 & 0.468 \\
Lower 95\% Cl of mean & 12.3 & 6.51 & 108 & 120 & 69.3 & 86.2 & 50.2 & 70 \\
Upper 95\% Cl of mean & 13.9 & 6.74 & 110 & 122 & 70.8 & 87.7 & 51.7 & 71.8 \\
Coefficient of variation & $70.03 \%$ & $20.30 \%$ & $10.62 \%$ & $10.04 \%$ & $13.05 \%$ & $10.64 \%$ & $17.82 \%$ & $16.13 \%$ \\
\hline
\end{tabular}

Table 2. Average anthropometric values of students from Timisoara University centre

\begin{tabular}{|c|c|c|c|c|c|}
\hline & $\begin{array}{l}\text { Weight } \\
\text { [Kg] }\end{array}$ & $\begin{array}{l}\text { Circumference of } \\
\text { Abdomen [cm] }\end{array}$ & Waist-Hip Ratio & $\begin{array}{l}\text { Soft Lean Mass } \\
{[\mathrm{Kg}]}\end{array}$ & $\begin{array}{l}\text { Skeletal Muscle Mass } \\
{[\mathrm{Kg}]}\end{array}$ \\
\hline Minimum & 38.5 & 42.9 & 0.73 & 7.8 & 15.8 \\
\hline Maximum & 128 & 130 & 1.08 & 89.1 & 55.2 \\
\hline Mean & 67.9 & 81.7 & 0.834 & 44.5 & 29 \\
\hline Std. Deviation & 16.6 & 12.9 & 0.0573 & 13.1 & 7.48 \\
\hline Std. Error & 0.674 & 0.618 & 0.00274 & 0.548 & 0.357 \\
\hline Lower $95 \% \mathrm{Cl}$ of mean & 66.6 & 80.5 & 0.829 & 43.4 & 28.3 \\
\hline Upper $95 \% \mathrm{Cl}$ of mean & 69.2 & 82.9 & 0.84 & 45.5 & 29.7 \\
\hline Coefficient of variation & $24.46 \%$ & $15.84 \%$ & $6.87 \%$ & $29.55 \%$ & $25.79 \%$ \\
\hline
\end{tabular}

Table 3. Average body composition values of students from Timisoara University centre

\begin{tabular}{|c|c|c|c|c|c|c|c|c|}
\hline & $\begin{array}{l}\text { Body Fat } \\
\text { Mass [Kg] }\end{array}$ & $\begin{array}{l}\text { Percentage } \\
\text { Body Fat [\%] }\end{array}$ & $\begin{array}{l}\text { Fat Mass of } \\
\text { Right Arm } \\
\text { [Kg] }\end{array}$ & $\begin{array}{l}\text { Fat Mass of } \\
\text { Left Arm [Kg] }\end{array}$ & $\begin{array}{l}\text { Fat } \\
\text { Mass of } \\
\text { Trunk } \\
{[\mathrm{Kg}]}\end{array}$ & $\begin{array}{l}\text { Fat Mass } \\
\text { of Right } \\
\text { Leg [Kg] }\end{array}$ & $\begin{array}{l}\text { Fat Mass } \\
\text { of left Leg } \\
\text { [Kg] }\end{array}$ & $\begin{array}{l}\text { Visceral } \\
\text { Fat Area } \\
\left(\mathrm{cm}^{2}\right)\end{array}$ \\
\hline Minimum & 2.6 & 7.9 & 0.09 & 0.09 & 0.1 & 0.62 & 0.63 & 12 \\
\hline Maximum & 64.8 & 53 & 8.01 & 8.05 & 25.9 & 11.1 & 10.9 & 203 \\
\hline Mean & 18.2 & 26.1 & 1.21 & 1.24 & 9.08 & 2.78 & 2.76 & 56.4 \\
\hline Std. Deviation & 9.44 & 8.85 & 0.976 & 0.981 & 4.93 & 1.29 & 1.28 & 41.5 \\
\hline Std. Error & 0.451 & 0.37 & 0.0466 & 0.0469 & 0.235 & 0.0618 & 0.0613 & 1.83 \\
\hline $\begin{array}{l}\text { Lower } 95 \% \mathrm{Cl} \text { of } \\
\text { mean }\end{array}$ & 17.3 & 25.4 & 1.12 & 1.14 & 8.62 & 2.66 & 2.64 & 52.8 \\
\hline $\begin{array}{l}\text { Upper } 95 \% \mathrm{Cl} \text { of } \\
\text { mean }\end{array}$ & 19.1 & 26.8 & 1.31 & 1.33 & 9.54 & 2.9 & 2.88 & 60 \\
\hline $\begin{array}{l}\text { Coefficient of } \\
\text { variation }\end{array}$ & $51.94 \%$ & $33.90 \%$ & $80.41 \%$ & $79.46 \%$ & $54.26 \%$ & $46.53 \%$ & $46.49 \%$ & $73.57 \%$ \\
\hline
\end{tabular}




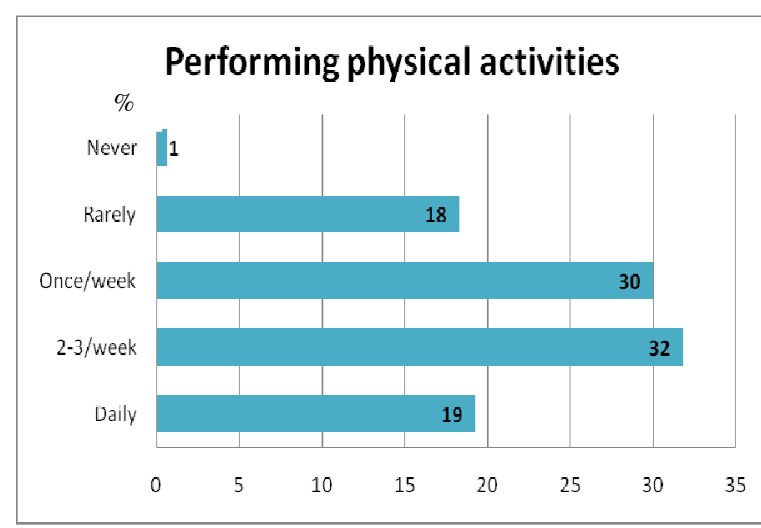

Figure 1. Physical activity performed by the students from target group (\%)

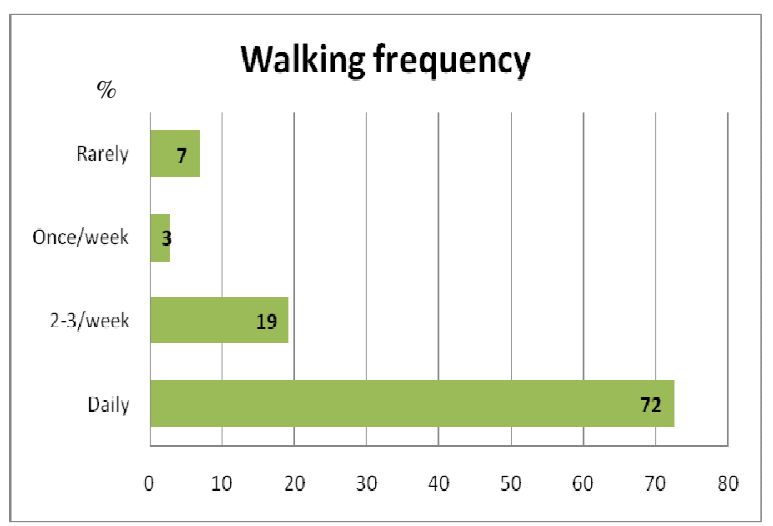

Figure 3. Walking frequency in target group

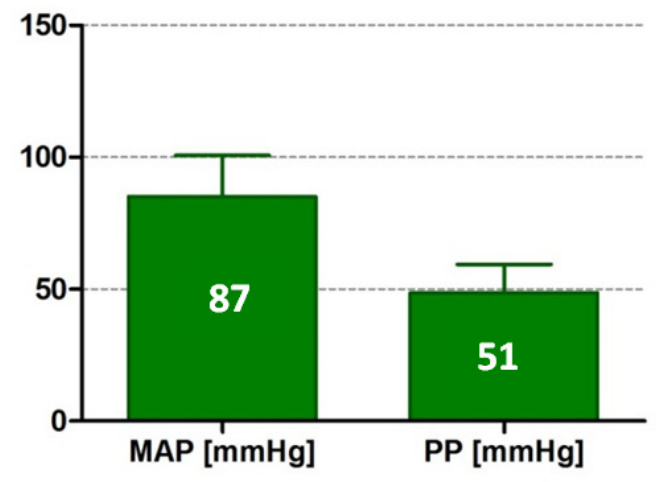

Figure 5. Medium arterial pressure (MAP) and pulse pressure (PP) in study group

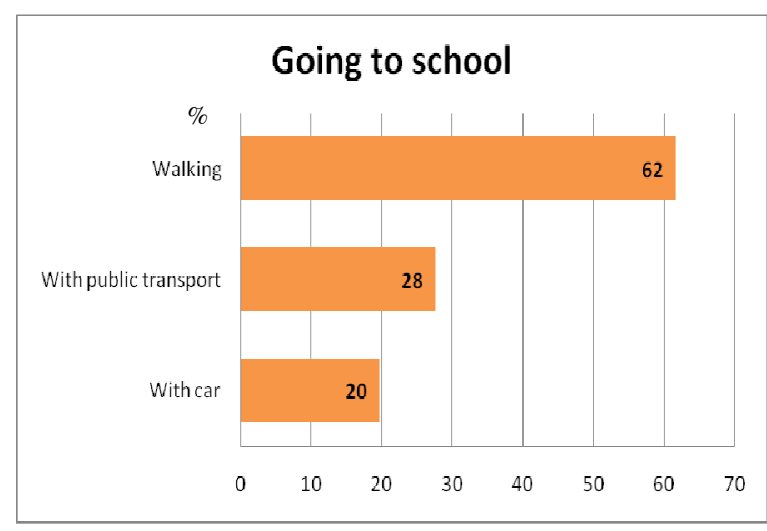

Figure 2. Transportation modalities used by the students from target group (\%)

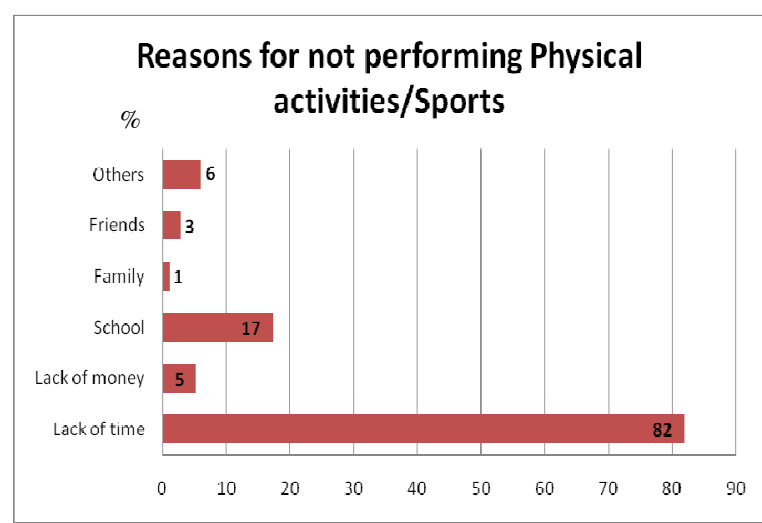

Figure 4. Reasons for not performing physical activities in target group

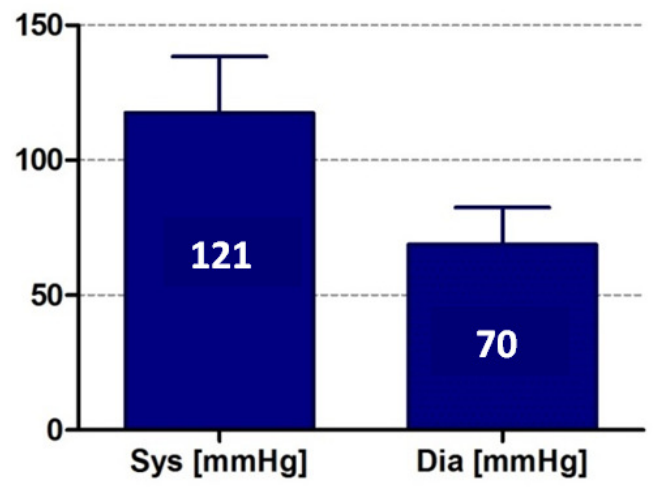

Figure 6. Systolic (Sys) and dyastolic (Dia) blood pressure in study group 


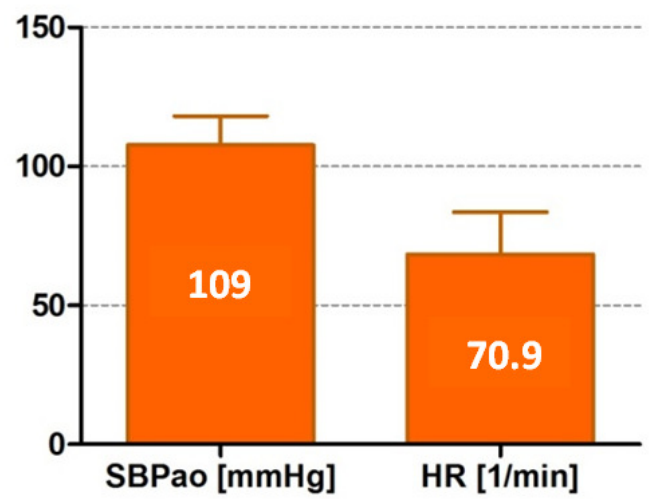

Figure 7. Central aortic systolic blood pressure and heart rate in study group

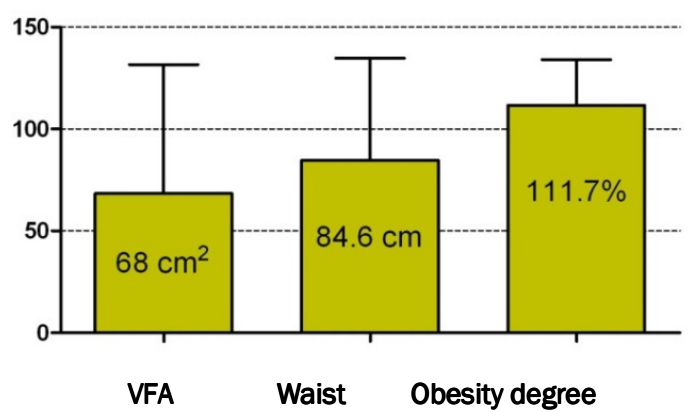

Figure 9. Visceral Fat Area (VFA), waist and obesity degree in study group

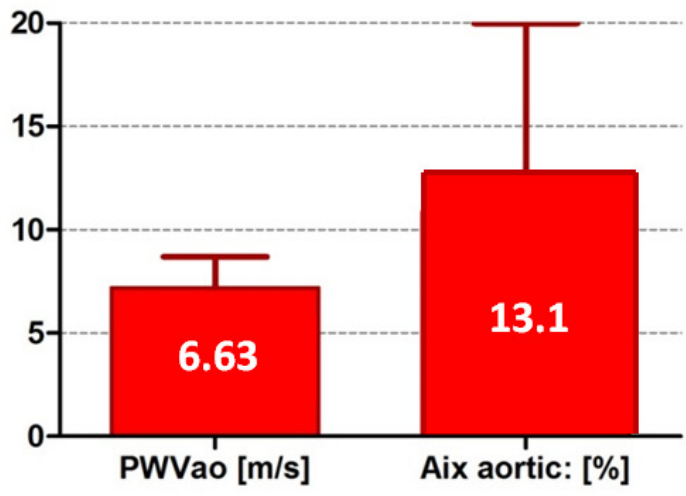

Figure 8. Pulse wave velocity (PVWao) and augmentation index (Aix aortic) in study group

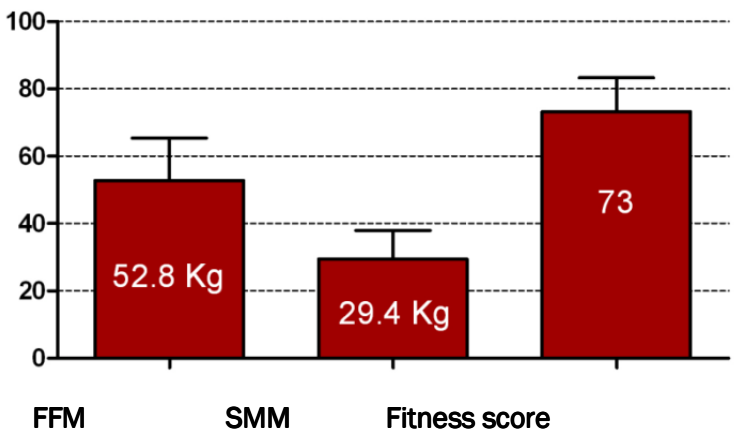

Figure 10. Fat free mass (FFM), skeletal muscle mass (SMM) and Fitness score in study group

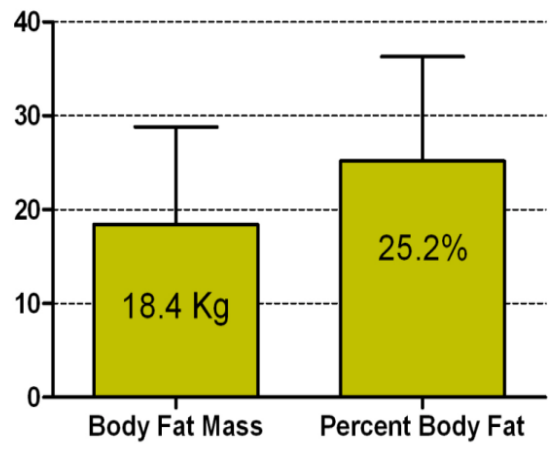

Figure 11. Composition in fat tissue in study group

The linear regression analysis showed that there is a positive relation between body mass index, pulse wave velocity $\left(r^{2}=0.34, p<0.001\right)$, central systolic blood pressure $\left(r^{2}=0.24, p<0.001\right)$, resting heart rate $\left(r^{2}=0.22\right.$, $p<0.001)$ [60]. Waist circumference correlates significantly with pulse wave velocity $\left(r^{2}=0.24, p<0.001\right)$ and resting heart rate $\left(r^{2}=0.14, p<0.001\right)$. 


\section{Disscussions and conclusion}

An important part of the assessed parameters (presented in table I-III) were positioned in the category of cardiovascular risk factors among evaluated students; this certify once again the importance of establishing a healthy lifestyle amomg them.

The parameters that are "positive" signs from cardiovascular risk in the target group are: augmentation index (abnormal values $>10 \%$ ), puls pressure (increased values over $40 \mathrm{mmHg}$ ), mean arterial pressure (increased, over $80 \mathrm{mmHg}$ ) [6, 7]. Even the other parameters are, as means, in normal range, the cardio-vascular risk is present and is not related in this case with a high visceral fat area, or with a high percentage of body fat; further analysis will be made (on the entire group of 1000 students) and correlated with the physical activity level and the eating behaviors of these students in order to establish the relation between these aspects.

After closure, we suppose that the target group formed by 600 students from Timișoara will have a better quality of life for medium and long-term, with better nutritional habits, despite to our common traditions. We suppose that the incidence of cardiometabolic diseases - a common threat in this area will decrease due to this kind of action.

The obesity management is a complex and difficult issue; such a cross-border prospective for a common health problem, was innovative from the point of view of its transdisciplinary approach; our team consisted from doctors, kinetotherapists and physical education teachers - so the main aspects (dietary counselling and physical training) of obesity treatment are covered. Other innovative aspects of our project were the assessment of cardiometabolic risk on a young and overweight population, followed by reinforcement in lifestyle changes, and the use of activemeters for monitoring the daily physical activity and exercise training intensity. This structured intervention was costeffective and had a positive impact on the onset of obesity related cardio-metabolic diseases (diabetes mellitus, ischemic heart disease, stroke etc.). At present, there is no other cross-border cooperation on this theme, despite the fact that obesity is a wellknown healthy problem in both countries [2, 3].

The possibility of generating multiplying effects resides in the remarkable dissemination capacity of the partners. These dissemination actions can reach institutional dimensions by assimilating the most efficient training modules of the target groups, thus generating multiplying effects. The project can represent a model for other institutions, associations and public authorities. The network of communication and cooperation between the two partners, initiated during the project, will be enlarged by attracting new members. Another source of multiplication of the project results resides from promoting the advantages to the beneficiaries, and the increase in the number of partnerships between the two partners in the project. The partnership created during the project implementation, will be expanded from the point of view of diversity, complexity and cross-border impact, becoming an important information tool on both sides of the border [2, 3].

Previous studies demonstrated that obesity increases the risk for developing diabetes mellitus, acute cardiovascular events and stroke [16-18]. Increased arterial stiffness is an independent predictor of cardiovascular diseases. This study suggests that obesity degree and abdominal obesity is associated with an increased aortic blood pressure and arterial stiffness in apparently healthy young obese individuals [19]. These results demonstrates once again that prevention programs 
should be addressed to young people to reduce their cardiovascular risk.

A follow-up after 5 years (in 2017) was proposed using the database of subjects investigated during the project implementation; every year (between 2012 and 2017) we will try to assess these students (for body composition and cardiometabolic risk) in order to investigate the progression of the cardio-metabolic risk factors, and the onset of obesity related disease. In the same time we will reinforce them to maintain the healthy habits gained during the project implementation. Moreover, the partners agree on developing the cooperation initiated in the project with other similar organizations. The results of the project were made public and were put at the disposal of everyone interested.

\section{References}

1. http://www.huro-cbc.eu/en/project_info/1209, accessed on 20th of September, 2013;

2. http://www.riskred.eu/, accessed in 20th of September, 2013;

3. Oravițan M., Avram C., Iurciuc S., Fehérné-Kiss A., Barnai M. (2012) Obesity and cardiometabolic risk management in students from Timișoara and Szeged University Centres, publicată în Timisoara Physical Education and Rehabilitation Journal, vol.4, 8: 42-52;

4. Kotseva K., Wood D., De Backer G., De Bacquer D., Pyörälä K., Keil U. (2009) Cardiovascular prevention guidelines in daily practice: a comparison of EUROASPIRE I, II, and III surveys in eight European countries, The Lancet, vol. 373, 9667: 929-940;

5. http://www.romanianheart.ro/en/who-we-are/objectives53.html, accessed in 19 th of March, 2011;

6. Blacher J., Guerin A.P., Pannier B., Marchais S.J., Safar M.E., London, G.M. (1999) Impact of aortic stiffness on survival in end-stage renal disease, Circulation, 99: 2434-2439;
7. Davies J., Struthers A. (2003) Assessment of central arterial pressure? Authors' reply, Journal of Hypertension, 21(7): 463472;

8. Shimizu M., Kario K. (2008) Role of the augmentation index in hypertension, Therapeutic Advances in Cardiovascular Disease, 2: 25-35;

9. Oliver J.J., Webb J. (2003) Noninvasive Assessment of Arterial Stiffness and Risk of Atherosclerotic Events, Arteriosclerosis, Thrombosis, and Vascular Biology, 23: 554-566;

10. Wenn C.M., Newman D.L. (1990) Arterial tortuosity, Australasian Physical and Engineering Sciences in Medicine, 13: $67-70$;

11. Boutouyrie P., Tropeano A.I., Asmar R., Gautier I., Benetos A., Lacolley, P., Laurent, S. (2002) Aortic stiffness is an independent predictor of primary coronary events in hypertensive patients: a longitudinal study, Journal of Hypertension, 39: 10-15;

12. Benetos A., Adamopoulos C., Bureau J.M., Temmar M., Labat C., Bean K., Thomas F., Pannier B., Asmar R., Zureik M., Safar, M., Guize L. (2002) Determinants of accelerated progression of arterial stiffness in normotensive subjects and in treated hypertensive subjects over a 6-year period, Circulation, 105: 1202-1207;

13. Blacher J., Asmar R., Djane S., London G.M., Safar M.E. (1999) Aortic pulse wave velocity as a marker of cardiovascular risk in hypertensive patients, Journal of Hypertension, 33: 1111-1117;

14. Avram C., Oravitan M. (2013) Fruit, vegetables and fast food consumption among university students, Timişoara Physical Education and Rehabilitation Journal, vol. 5, 10:50-58;

15. Gagey P.M., Bizzo G., Bonnier L., Gentaz R., Guillaume P., Marucchi, C. (1993) Huit leçons de posturologie, Association française de posturologie, Paris;

16. European Guidelines on cardiovascular disease prevention in clinical practice (2012) European Heart Journal, 28: 23752414;

17. European Guidelines on diabetes, pre-diabetes, and cardiovascular diseases (2007) European Heart Journal Volume 28, 1: 88-136;

18. Perk J., De Backer G., Gohlke H., Graham I., Reiner Z., Verschuren M. et al. (2012) European Guidelines on cardiovascular disease prevention in clinical practice, European Heart Journal, 33: 1635-1701;

19. Avram C., Oravițan M., Nagel A., Almăjan-Guță B., Drăgoi R.G. (2013) Relation between obesity and arterial stiffness in young individuals, Proceedings of the 7th World Congress of the International Society of Physical and Rehabilitation Medicine, pp. 221- 224. 